\title{
Model diskursus multi representasi dan kemampuan pemahaman konsep matematika siswa sekolah menegah pertama
}

\author{
Kadek Pasek Budarsini *, I Made Suarsana, I Nengah Suparta \\ Jurusan Matematika, Universitas Pendidikan Ganesha. \\ Jalan Udayana No. 11, Kota Singaraja, Bali 81116, Indonesia \\ * Corresponding Author. E-mail: pasek_budarsini@yahoo.com \\ Received: 21 June 2018; Revised: 9 August 2018; Accepted: 17 September 2018
}

\begin{abstract}
Abstrak
Penelitian ini merupakan penelitian eksperimen semu yang bertujuan untuk mengetahui pengaruh model pembelajaran Diskursus Multi Representasi terhadap kemampuan pemahaman konsep matematika siswa kelas VII SMP Negeri 5 Singaraja, Provinsi Bali. Desain penelitian yang digunakan dalam penelitian ini adalah post-test only control group design. Populasi penelitian ini adalah seluruh siswa kelas VII SMP Negeri 5 Singaraja semester genap tahun ajaran 2017/2018. Sampel penelitian ditentukan dengan teknik cluster random sampling dan terpilih 2 kelas yakni kelas VII H dan kelas VII I sebagai sampel penelitian. Melalui pengundian kelas VII I dipilih sebagai kelas eksperimen dan kelas VII H sebagai kelas kontrol. Data mengenai pemahaman konsep matematika siswa dikumpulkan dengan menggunakan tes essay dan selanjutnya dianalisis dengan menggunakan uji- $t$ satu arah (onetailed) pada taraf signifikansi $5 \%$. Hasil analisis data menunjukkan bahwa nilai $t_{\text {hitung }}=2,037$ dan $t_{\text {tabel }}$ $=1,671$, tampak bahwa $t_{\text {hitung }} \geq t_{\text {tabel }}$ yang berarti hipotesis nol ditolak. Dari hasil tersebut dapat disimpulkan bahwa kemampuan pemahaman konsep matematika siswa kelas VII SMP Negeri 5 Singaraja yang dibelajarkan model pembelajaran Diskursus Multi Representasi lebih baik dari kemampuan pemahaman konsep matematika siswa yang dibelajarkan dengan model pembelajaran konvensional.
\end{abstract}

Kata Kunci: model diskursus multi representasi, pemahaman konsep matematika

\section{Multiple representation discourse model and the ability of understanding the mathematical concept of students of junior high school}

\begin{abstract}
This research was a quasi-experimental research that aimed to determine the effect of Multiple Representation Discourse learning model towards the ability of understanding the mathematical concept of VII grade students of SMP Negeri 5 Singaraja, Province of Bali, Indonesia. The research design used in this research was post-test only control group design. The population of this study were all students of grade VII of SMP Negeri 5 Singaraja in second semester of academic year 2017/2018. The sample of the research was determided by cluster random sampling technique. The use of this technique was done by drawing the 11 classes. One class was taken randomly to be become experimental class and the other one as control class. Data of students' mathematics concept understanding were collected by using the essay test and were analyzed by using a one-tailed test at significance level of 5\%. The results showed that $t_{\text {count }}=2.037$ and $t_{\text {table }}=1.671$, which means that the hypothesis null was rejected. This indicated that the application of the Multiple Representation Discourse model positively significantly affects the students' understanding on mathematical concepts. Keywords: multiple representation discourse model, understanding of mathematical concepts
\end{abstract}

How to Cite: Budarsini, K., Suarsana, I., \& Suparta, I. (2019). Model diskursus multi representasi dan kemampuan pemahaman konsep matematika siswa sekolah menengah pertama. Pythagoras: Jurnal Pendidikan Matematika, 13(2), 109-117. doi:https://doi.org/10.21831/pg.v13i2.20047

doi https://doi.org/10.21831/pg.v13i2.20047

\section{PENDAHULUAN}

Matematika merupakan salah satu disiplin ilmu yang bermanfaat bagi kehidupan dan disiplin ilmu lainnya. Pemahaman konsep matematika dapat diartikan sebagai kemampuan dalam memahami ide-ide abstrak untuk mengklasifikasikan objek-objek atau peristiwa-peristiwa 
dalam matematika. Kemampuan pemahaman konsep memiliki peranan penting (Hendrayana, 2017), terutama untuk mengembangkan pola pikir siswa, namun pada kenyataannya kemampuan pemahaman konsep siswa masih dikatakan cukup rendah. Penelitian Mawaddah (2016) menemukan beberapa permasalahan dalam pembelajaran matematika di kelas, di antaranya siswa masih mengalami kesulitan dalam menggunakan operasi hitung pada aljabar. Masalah lain yang ditemukan adalah sebagian siswa masih terbiasa menghafal rumus tanpa memahami secara mendalam materi yang dipelajari. Hal ini mengakibatkan siswa mengalami kesulitan dalam memilih atau mengklasifikasikan rumusrumus yang digunakan untuk menyelesaikan suatu masalah matematika. Selain itu, siswa juga mengalami kesulitan dalam membedakan contoh dan bukan contoh yang berhubungan dengan materi. Hal ini diperkuat dengan hasil pekerjaan siswa pada saat mengerjakan soal-soal ulangan harian dan Ujian Tengah Semester (UTS), sehingga disimpulkan bahwa pada dasarnya kemampuan pemahaman matematika siswa masih rendah. Hal ini ditegaskan pula oleh Rojak (2017) yang menyatakan bahwa kemampuan pemahaman konsep siswa masuk dalam kategori kurang, hal ini dapat dilihat dari skor yang diperoleh siswa setelah menjawab tes berbentuk uraian yaitu 12,31 dari skor ideal 30 atau dapat dikatakan siswa hanya mampu menjawab 41,03\% dan masuk dalam kategori kurang. Hal serupa juga dikemukakan oleh Nugraheni \& Sugiman (2013) yang mana dalam penelitiannya juga ditemukan fakta bahwa pemahaman konsep siswa dalam menyelesaikan masalah matematika masih rendah.

Alamsyah (2017) menyatakan bahwa rendahnya pemahaman konsep matematika disebabkan oleh dua faktor yaitu faktor internal dan faktor eksternal. Faktor internal yaitu kemampuan intelektual siswa sedangkan faktor eksternal yaitu faktor pedagogis atau cara mengajar guru dikelas yang monoton, sedangkan menurut Hamzah (2012) menyatakan bahwa aktivitas belajar berpengaruh terhadap pemahaman konsep matematika siswa kelas VII MTs. Amelia (Tianingrum, 2017) menyatakan bahwa penyebab rendahnya pemahaman siswa terhadap matematika berakar pada siswa yang cenderung menghafal konsep daripada proses penguasaan konsep. Apabila ditelusuri dari beberapa uraian faktor rendahnya pemahaman konsep, faktor yang mendominasi adalah aktivitas pembelajaran yang dilalui siswa. Proses pembelajaran pada saat ini sebagian besar masih berpusat pada guru sehingga di dalam proses pembelajaran aktivitas siswa kurang aktif. Hal ini ditegaskan oleh Yaumi (2012, p.1) bahwa pendekatan yang berpusat pada guru (teacher-centered approach) cenderung mendominasi pelaksanaan pembelajaran saat ini, sehingga diperlukan pembelajaran yang lebih inovatif.

Salah satu karakteristik matematika yaitu sebagai sistem lambang bilangan yang berstruktur abstrak (Uno, 2012). Materi matematika yang lebih abstrak dapat diajarkan dengan menggunakan media atau alat pembelajaran maupun penjelasan yang lebih bersifat konkret sehingga siswa dapat belajar dari tahap konkret ke tahap yang lebih abstrak. Hal ini sejalan dengan pendapat Hudojo (2007, p.2) bahwa dalam pembelajaran matematika yang abstrak, siswa memerlukan alat bantu berupa media dan alat peraga yang dapat memperjelas apa yang disampaikan oleh guru sehingga lebih mudah dipahami dan dimengerti siswa. Hal ini sejalan pula dengan teori belajar Bruner yaitu proses pembelajaran yang dilalui siswa melalui tahap enaktif, tahap ikonik dan tahap simbolik. Berdasarkan hal tersebut, maka di dalam proses pembelajaran siswa memerlukan media, alat maupun sumber pembelajaran baik dalam bentuk verbal, gambar, grafik dan persamaan matematis yang disebut representasi. Hal ini sejalan dengan salah satu indikator pemahaman konsep menurut Permendikbud Nomor 58 Tahun 2014 yaitu menyajikan konsep dalam berbagai macam bentuk representasi matematis (tabel, grafik, gambar, sketsa, model matematika, atau cara lainnya). Pemahaman konsep dapat ditanamkan kepada siswa melalui berbagai representasi, penggunaan representasi yang beragam dalam menyelesaikan suatu permasalahan disebut multi representasi (Darmastini \& Rosyidi, 2014, p.57).

Menurut Goldin (Kartini, 2009) representasi adalah suatu konfigurasi (bentuk atau susunan) yang dapat menggambarkan, mewakili atau melambangkan sesuatu dalam suatu cara seperti verbal, diagram, grafik, simulasi komputer, persamaan matematika. Sedangkan menurut Sabirin (2014) representasi merupakan model atau bentuk pengganti dari suatu situasi masalah yang dapat digunakan untuk menemukan solusi seperti gambar, kata-kata atau simbol matematika. Seorang guru menggunakan berbagai teknik representasi yang berbeda untuk menjelaskan informasi kepada siswa, selain teks guru menggunakan diagram, demonstrasi praktis, model matematika abstrak dan representasi 
lainnya untuk menanamkan konsep matematika kepada siswa, representasi yang digunakan guru dalam proses pembelajaran untuk menanamkan konsep pada siswa dapat dituangkan di dalam lembar kerja siswa sehingga siswa dituntun untuk melatih representasinya hal ini akan mengakibatkan pada pembentukan konsep matematika siswa (van Someren, Reimann, Boshuizen, \& De Jong, 1997). Di dalam proses pembelajaran dengan penerapan multi representasi akan mengakibatkan terjadinya suatu diskusi baik antara siswa dengan siswa, siswa dengan guru maupun siswa dengan lingkungan pembelajaran. Komunikasi yang terbentuk berupa komunikasi verbal, hal ini erat kaitannya dengan pembelajaran diskursus.

Pembelajaran diskursus merupakan disiplin ilmu yang menyelidiki hubungan antara bentuk dan fungsi dari komunikasi verbal (Renkema, 1993). Komunikasi verbal merupakan suatu komunikasi yang disampaikan kepada pihak lain dalam bentuk lisan dan tertulis, salah satu bentuk komunikasi verbal dalam proses pembelajaran yaitu presentasi diskusi. Dalam pembelajaran diskursus aktivitas yang dibangun bukan hanya mengomunikasikan sesuatu dalam bentuk kata atau bahasa tetapi juga digunakan sistem simbol nonlinguistic secara bersamaan yaitu teknologi, objek dan alat (Paul, 2003).

Purwasih (2013) menjelaskan bahwa Diskursus Multi Representasi merupakan salah satu pembelajaran matematika yang berorientasi pa- da siswa. Sedangkan menurut Suyatno (2009, p.69) model pembelajaran Diskursus Multi Representasi merupakan pembelajaran yang berorientasi pada pembentukan, penggunaan dan pemanfaatan berbagai representasi dengan setting kelas dan kerja kelompok. Selain itu, hasil penelitian Purwasih \& Bernad (2018) menunjukkan bahwa peningkatan kemampuan komunikasi matematis menggunakan model pembelajaran Diskursur Multi Representasi lebih baik dibandingkan dengan menggunakan model pembelajaran konvensional, serta model pembelajaran Diskursus Multi Representasi ini juga berpengaruh terhadap disposisi matematis peserta didik. Adapun representasi yang digunakan dalam proses pembelajaran yaitu berbentuk verbal, gambar, grafik, persamaan matematis, simulasi komputer dan alat berupa benda konkret, hal ini digunakan dengan tujuan agar siswa dapat berfikir lebih konkret dan dapat melihat simulasi langsung dari konsep yang diajarkan sehingga dapat menanamkan suatu konsep kepada siswa.

Berdasarkan paparan tersebut maka peneliti tertarik untuk mengajukan penelitian lebih lanjut yang dapat memengaruhi kemampuan pemahaman konsep matematika siswa menjadi lebih baik. Dengan demikian, tujuan penelitian inilah ada untuk mengetahui pengaruh model pembelajaran Diskursus Multi Representasi terhadap kemampuan pemahaman konsep matematika siswa kelas VII SMP Negeri 5 Singaraja, Provinsi Bali.

Tabel 1. Rubrik Penskoran Penilaian Pemahaman Konsep Matematika Siswa

\begin{tabular}{|c|c|c|}
\hline Indikator Pemahaman Konsep & Skor & Kategori \\
\hline \multirow{3}{*}{$\begin{array}{l}\text { Menyatakan ulang konsep yang } \\
\text { dipelajari dengan kata-kata } \\
\text { sendiri. }\end{array}$} & 2 & $\begin{array}{l}\text { Menyatakan ulang konsep yang telah dipelajari dengan kata-kata } \\
\text { sendiri dengan benar. }\end{array}$ \\
\hline & 1 & $\begin{array}{l}\text { Menyatakan ulang konsep yang telah dipelajari dengan kata-kata } \\
\text { sendiri namun belum sepenuhnya benar. }\end{array}$ \\
\hline & 0 & $\begin{array}{l}\text { Tidak membuat jawaban atau membuat jawaban tetapi jauh dari } \\
\text { yang diharapkan. }\end{array}$ \\
\hline \multirow{3}{*}{$\begin{array}{l}\text { Mengidentifikasi yang } \\
\text { merupakan contoh dan bukan } \\
\text { contoh dari suatu konsep. }\end{array}$} & 2 & $\begin{array}{l}\text { Mengidentifikasi yang termasuk contoh atau bukan contoh dari } \\
\text { suatu konsep dengan benar. }\end{array}$ \\
\hline & 1 & $\begin{array}{l}\text { Mengidentifikasi yang termasuk contoh atau bukan contoh dari } \\
\text { suatu konsep namun belum sepenuhnya benar. }\end{array}$ \\
\hline & 0 & $\begin{array}{l}\text { Tidak membuat jawaban atau membuat jawaban tetapi jauh dari } \\
\text { yang diharapkan.. }\end{array}$ \\
\hline \multirow[t]{5}{*}{$\begin{array}{l}\text { Mengaplikasikan konsep dalam } \\
\text { berbagai situasi. }\end{array}$} & 4 & $\begin{array}{l}\text { Mengaplikasikan konsep dalam berbagai situasi, perhitungan dan } \\
\text { jawaban akhir benar. }\end{array}$ \\
\hline & 3 & $\begin{array}{l}\text { Benar mengaplikasikan konsep dalam berbagai situasi, sebagian } \\
\text { besar perhitungan benar namun jawaban akhir salah. }\end{array}$ \\
\hline & 2 & $\begin{array}{l}\text { Benar mengaplikasikan konsep dalam berbagai situasi, namun } \\
\text { perhitungan dan jawaban akhir salah. }\end{array}$ \\
\hline & 1 & Tidak benar dalam mengaplikasikan konsep dalam berbagai situasi. \\
\hline & 0 & $\begin{array}{l}\text { Tidak menuliskan jawaban hanya menyampaikan ulang informasi } \\
\text { yang telah disediakan. }\end{array}$ \\
\hline
\end{tabular}



Pythagoras, 13 (2), 2018 - 113

Kadek Pasek Budarsini, I Made Suarsana, I Nengah Suparta

\section{METODE}

Jenis penelitian ini adalah penelitian eksperimen dalam kategori penelitian eksperimen semu (quasi-eksperimental), karena tidak seluruh variabelnya atau gejala-gejala yang muncul diatur dan dikontrol secara ketat. Menurut Sugiyono (2009), penelitian semu dapat digunakan untuk melihat pengaruh yang ditimbulkan dari perlakuan berbeda yang diberikan pada masingmasing kelompok, dimana peneliti tidak dapat mengontrol semua variabel dan kondisi eksperimen secara ketat. Penelitian eksperimen ini bertujuan untuk mengetahui pengaruh model pembelajaran Diskursus Multi Representasi terhadap kemampuan pemahaman konsep matematika siswa kelas VII SMP Negeri 5 Singaraja.

Penelitian dilaksanakan di SMP Negeri 5 Singaraja yang berlokasi di Desa Penglatan, Kecamatan Buleleng, Kabupaten Buleleng, Provinsi Bali, Indonesia. Penelitian dimulai dari 9 Maret 2018 sampai dengan 13 April 2018. Populasi dari penelitian ini adalah siswa kelas VII SMP Negeri 5 Singaraja tahun ajaran 2017/ 2018. Banyak populasi pada penelitian ini adalah 341 yang terdistribusi ke dalam 11 kelas. Berdasarkan informasi yang diperoleh dari guru matematika kelas VII SMP Negeri 5 Singaraja menyatakan bahwa kesebelas kelas tersebut telah terdistribusi ke dalam kelas-kelas yang tingkat kemampuan akademiknya setara, hal ini dikarenakan siswa telah disebar dan dikelompokkan ke dalam kelas-kelas secara merata baik yang memiliki kemampuan akademik tinggi, sedang maupun rendah, sehingga tidak terdapat kelas unggulan maupun non unggulan. Teknik pengambilan sampel pada penelitian ini menggunakan teknik cluster random sampling terhadap kelas yang telah terbentuk di sekolah. Mulamula dilakukan pengundian untuk memperoleh dua kelas sebagai sampel, dari dua kelas yang terpilih akan diundi kembali untuk menentukan satu kelas sebagai kelompok eksperimen dan satu kelas sebagai kelompok kontrol. Dari hasil pengundian, diperoleh kelas VII I sebagai kelas eksperimen dan kelas VII H sebagai kelas kontrol.

Langkah-langkah yang dilakukan pada penelitian ini yaitu: (1) menentukan sekolah yang akan dijadikan sebagai tempat penelitian yaitu SMP Negeri 5 Singaraja dan memohon izin pihak sekolah, (2) menentukan sampel penelitian berupa kelas dari populasi yang telah ditentukan dengan menggunakan teknik cluster random sampling diperoleh kelas VII I sebagai kelas eksperimen dan kelas VII H sebagai kelas kontrol, (3) merancang dan menyiapkan perangkat pembelajaran seperti RPP, LKS, dan tes essay. LKS yang digunakan adalah LKS multi representasi dimana penyelesaian LKS tersebut memuat lebih dari satu representasi seperti verbal, gambar, persamaan matematis, tabel, diagram dan simulasi komputer, (4) mengonsultasikan instrumen penelitian dengan guru dan dosen pembimbing untuk validasi, pembuktian validitas isi melalui expert judmente (uji pakar) dan dikuantifikasi menggunakan indeks validitas menurut Gregory dan diperoleh indeks validitas isi sebesar 1,00 yang menunjukkan bahwa instrumen penelitian memiliki angka validitas sangat tinggi atau dengan kata lain instrumen sangat relevan untuk digunakan. Tes pemahaman konsep sebanyak 6 butir soal diujicobakan di SMP Negeri 4 Singaraja. Selanjutnya dilakukan estimasi reliabilitas tes dengan menggunakan rumus Alpha Cronbach dan diperoleh koefisien reliabilitas 0,687 yang termasuk dalam kategori tinggi, (5) memberikan perlakuan model pembelajaran Diskursus Multi Representasi pada kelas eksperimen dan pembelajaran konvensional pada kelas kontrol, (6) memberikan post-test dalam bentuk tes essay kepada kelas eksperimen dan kelas kontrol, tes yang digunakan sebanyak 4 butir soal yang telah mencakup indikator pemahaman konsep, (7) menganalisis hasil penelitian untuk menguji hipotesis yang diajukan, dan (8) membuat laporan hasil penelitian.

Data dalam penelitian ini adalah data hasil tes pemahaman konsep matematika. Data dikumpulkan dengan pemberian post-test pada dua kelompok sampel, tujuannya untuk mengetahui kemampuan pemahaman konsep matematika setelah diberikan perlakuan. Adapun instrumen yang digunakan yaitu tes essay (uraian) pemahaman konsep matematika. Materi tes yang diberikan tentang soal-soal matematika kelas VII semester 2 yaitu segiempat dan segitiga. Pedoman penskoran yang digunakan pada penelitian ini yaitu mengacu pada pedoman penskoran menurut NCTM (2000) yang dimodifikasi sebagaimana disajikan pada Tabel 1 .

Data hasil tes kemampuan pemahaman konsep matematika dianalisis dengan menggunakan uji Kolmogorov-Smirnov yang bertujuan untuk mengetahui suatu data berdistribusi normal atau tidak. Uji Levene digunakan untuk mengetahui apakah kedua kelompok memiliki varians yang homogen atau tidak. Uji hipotesis yang diajukan dengan menggunakan uji- $t$ satu ekor (one-tailed). Apabila data berdistibusi nor- 
Pythagoras, 13 (2), 2018 - 114

Kadek Pasek Budarsini, I Made Suarsana, I Nengah Suparta

mal dan homogen digunakan uji-t satu ekor. Apabila data berdistribusi normal tetapi tidak homogen digunakan uji- $t$ dengan kriteria pengujian yang berbeda. Sedangkan apabila data tidak berdistribusi normal maka data dianalisis menggunakan statistik non parametrik yaitu uji $U$ Mann-Whitney.

Adapun hipotesis yang diajukan pada penelitian ini yaitu kemampuan pemahaman konsep matematika siswa kelas VII SMP Negeri 5 Singaraja yang dibelajarkan dengan model pembelajaran Diskursus Multi Representasi lebih baik daripada kemampuan pemahaman konsep matematika siswa kelas VII SMP Negeri 5 Singaraja yang dibelajarkan dengan model pembelajaran konvensional.

\section{HASIL DAN PEMBAHASAN}

\section{Hasil}

Hasil persentase skor tes pemahaman konsep (post-test) antara kelas eksperimen dan kelas kontrol terhadap indikator pemahaman konsep matematika dapat dilihat pada Tabel 2.

Tabel 2. Rangkuman Analisis Persentase Post

Test Kemampuan Pemahaman Konsep Matematika

\begin{tabular}{cll}
\hline \multirow{2}{*}{$\begin{array}{c}\text { IPK } \\
\text { ke- }\end{array}$} & \multicolumn{1}{c}{ Kelas Eksperimen } & \multicolumn{1}{c}{ Kelas Kontrol } \\
\cline { 2 - 3 } 1 & \multicolumn{1}{c}{ Skor dicapai (persentase) } \\
2 & $195(78,63 \%)$ & $163(67,92 \%)$ \\
3 & $212(85,48 \%)$ & $58(96,67 \%)$ \\
\hline
\end{tabular}

Keterangan:

IPK ke-1, 2 dan 3 dapat dilihat pada Tabel 1.

Tampak bahwa pada Tabel 2 persentase skor kelas ekperimen lebih tinggi dibandingkan dengan skor kelas kontrol pada setiap indikator yang diukur, terutama pada indikator pertama yaitu menyatakan ulang konsep yang dipelajari dengan kata-kata sendiri yang memiliki rentang persentase antara kelas eksperimen dan kelas kontrol adalah $10,71 \%$. Hal ini menunjukkan bahwa siswa kelas eksperimen memiliki kemampuan pemahaman konsep matematika lebih baik daripada kelas kontrol.

Dari data yang telah terkumpul diperoleh bahwa rata-rata skor pemahaman konsep matematika siswa pada kelompok eksperimen adalah 21,81 dan rata-rata skor pemahaman konsep matematika siswa pada kelompok kontrol adalah 19,23. Rangkuman hasil analisis data pemahaman konsep matematika siswa pada kelompok eksperimen dan kelompok kontrol ditunjukkan pada Tabel 3 .
Tabel 3. Rangkuman Hasil Analisis Data Pemahaman Konsep Matematika Siswa

\begin{tabular}{ccc}
\hline \multirow{2}{*}{ Variabel } & \multicolumn{2}{c}{ Skor Post-Test } \\
\cline { 2 - 3 } & $\begin{array}{c}\text { Kelompok } \\
\text { Eksperimen }\end{array}$ & $\begin{array}{c}\text { Kelompok } \\
\text { Kontrol }\end{array}$ \\
\hline$n$ & 31 & 30 \\
$\bar{X}_{(\%)}$ & $21,81(77,88 \%)$ & $19,23(68,69 \%)$ \\
$S^{2}$ & 17,96 & 14,39 \\
$S$ & 4,24 & 3,79 \\
$S_{\text {gab }}^{2}$ & & 16,21 \\
\hline
\end{tabular}

Berdasarkan Tabel 3 tampak bahwa ratarata skor pemahaman konsep matematika siswa kelompok eksperimen yang mengikuti pembelajaran menggunakan model pembelajaran Diskursus Multi Representasi lebih tinggi daripada rata-rata skor pemahaman konsep matematika siswa kelompok kontrol yang mengikuti pembelajaran menggunakan pembelajaran konvensional.

Hasil analisis uji normalitas dengan uji Kolmogorov-Smirnov dperoleh hasil perhitungan normalitas data kemampuan pemahaman konsep matematika siswa pada kelompok eksperimen nilai $D_{\text {hitung }}=0,097$. Berdasarkan tabel Kolmogorv-Smirnov untuk taraf signifikan 5\% dan $n=$ 31 diperoleh $D_{\text {tabel }}=0,244$. Kemudian bandingkan nilai $D_{\text {hitung }}$ dengan $D_{\text {tabel }}$ sehingga diperoleh bahwa $D_{\text {hitung }}<D_{\text {tabel }}$ yaitu $0,097<0,244$, hal ini menunjukkan bahwa sebaran data kemampuan pemahaman konsep matematika siswa kelompok eksperimen berdistribusi normal. Pada kelompok kotrol diperoleh $D_{\text {hitung }}=0,088$ dan pada tabel Kolmogorv-Smirnov untuk taraf signifikan $5 \%$ dan $n=30$ diperoleh $D_{\text {tabel }}=0,248$ sehingga $D_{\text {hitung }}<D_{\text {tabel }}$ yaitu $0,088<0,248$, hal ini menunjukkan bahwa sebaran data kemampuan pemahaman konsep matematika siswa kelompok kontrol berdistribusi normal.

Hasil analisis uji homogenitas varians data pemahaman konsep matematika siswa dengan menggunakan uji Levene. Dari pengujian tersebut diperoleh nilai $F_{\text {hitung }}=1,248$. Berdasarkan tabel pada taraf signifikan 5\% dengan $d k$ penyebut $=30$ dan $d k$ penyebut $=29$ diperoleh $F_{\text {tabel }}=2,092$ sehingga $F_{\text {hitung }}<F_{\text {tabel }}$ yaitu $1,248<2,092$, hal ini berarti tidak ada perbedaan varian antara kelompok eksperimen dan kelompok kontrol (varian data homogen). Berdasarkan hasil uji normalitas dan homogenitas varians, diperoleh bahwa sebaran data pemahaman konsep matematika siswa pada kelompok eksperimen dan kelompok kontrol berdistribusi normal dan memiliki varians yang homogen. 
Pythagoras, 13 (2), 2018 - 115

Kadek Pasek Budarsini, I Made Suarsana, I Nengah Suparta

Oleh karena itu, uji hipotesis dapat dilakukan dengan uji- $t$ satu ekor.

Hasil uji hipotesis menggunakan uji- $t$ diperoleh nilai $t_{\text {hit }}=2,037$ dan $t_{\text {tabel }}=1,671$ pada taraf signifikan 5\% dan $d k=59$, sehingga $t_{\text {hit }} \geq \boldsymbol{t}_{\text {tabel }}$ yaitu $2,037 \geq 1,671$. Dari hal tersebut maka hipotesis nol ditolak, sehingga dapat disimpulkan bahwa kemampuan pemahaman konsep matematika siswa yang dibelajarkan model pembelajaran Diskursus Multi Representasi lebih baik dari kemampuan pemahaman konsep matematika siswa yang dibelajarkan dengan model pembelajaran konvensional.

\section{Pembahasan}

Hasil analisis terhadap skor pemahaman konsep matematika siswa menunjukkan bahwa rata-rata skor yang dicapai kelompok eksperimen lebih tinggi daripada rata-rata skor yang dicapai kelas kontorl yaitu 21,80 untuk kelas eksperimen dan 19,23 untuk kelas kontrol. Berdasarkan hasil uji hipotesis dengan menggunakan uji-t diperoleh bahwa $t_{\text {hitung }}=2,037$ dan $t_{\text {tabel }}=1,671$ untuk $d k=59$ dengan taraf signifikan 5\%, hal ini menunjukkan bahwa kemampuan pemahaman konsep matematika siswa yang dibelajarkan model Diskursus Multi Representasi lebih baik dari pada kemampuan pemahaman konsep matematika siswa yang dibelajarkan dengan pembelajaran konvensional. Dengan kata lain ada pengaruh positif dan kontribusi yang berarti dalam pembelajaran dengan menggunakan model Diskursus Multi Representasi terhadap pemahaman konsep matematika siswa.

Hal ini terjadi disebabkan karena adanya perbedaan perlakuan pada proses pembelajaran kelas eksperimen dan kelas kontrol. Proses pembelajaran pada kelas ekperimen menerapkan model pembelajaran Diskursus Multi Representasi sedangkan pembelajaran pada kelas kontrol menerapkan pembelajaran konvensional. Adapun langkah-langkah pembelajaran model ini menurut Suyatno (2009) yang diterapkan peneliti pada saat proses pembelajaran di kelas eksperimen berlangsung yaitu tahap persiapan, tahap pendahuluan, tahap pengembangan dan tahap penutup. Pada tahap persiapan, siswa diorganisasikan ke dalam beberapa kelompok dalam rangka menyelesaikan permasalahan dalam bentuk LKS yang diberikan guru melalui diskusi kelompok. Model pembelajaran ini menggunakan setting kelas dan kerja kelompok (Suyatno, 2009).

Pada tahap pendahuluan, siswa mengingat kembali materi yang telah dipelajari yang memi- liki keterkaitan dengan materi yang akan diajarkan, proses pembelajaran saat mengaitkan pengetahuan baru dengan pengetahuan yang sudah ada. Pada tahap pengembangan, siswa bersama kelompoknya memahami materi yang diajarkan dengan menyelesaikan permasalahan pada LKS, LKS yang diberikan kepada siswa menuntun siswa untuk memahami konsep dari suatu materi dimana dalam menanamkan konsep LKS yang dibuat guru mencakup representasi dalam penyelesaiannya, representasi yang ditampilkan pada LKS tersebut berupa gambar, persamaan matematis, menuntun siswa menggunakan alat dalam bentuk benda konkret dan simulasi komputer dalam penyelesaian LKS tersebut. Hal ini sejalan dengan pernyataan Someren et al. (1997) bahwa representasi yang digunakan guru dalam proses pembelajaran untuk menanamkan konsep pada siswa dapat dituangkan di dalam lembar kerja siswa sehingga siswa dituntun untuk melatih representasinya hal ini akan mengakibatkan pada pembentukan konsep matematika siswa.

Melalui berbagai representasi yang dituangkan oleh guru pada LKS diyakini mampu membangun konsep yang lebih baik pada siswa. Hal ini ditegaskan oleh Waldrip, Prain, \& Carolan (2010) dalam penelitiannya menunjukkan bahwa bentuk dari berbagai representasi dapat dianggap sebagai alat penting untuk membangun pemahaman siswa. LKS yang digunakan pada model Diskursus Multi Representasi adalah LKS multi representasi. Melalui LKS ini mengakibatkan aktivitas siswa di dalam pembelajaran menjadi lebih aktif karena siswa berkegiatan menggunakan representasi benda konkret, memperhatikan simulasi komputer maupun penggunaan representasi lainnya hal ini akan mengakibatkan pembelajaran menjadi lebih bermakna, dalam teori Ausubel menyatakan bahwa pembelajaran matematika yang bermakna mencakup belajar matematika melalui kegiatan tidak sekedar hafalan. Selain mengakibatkan aktivitas siswa menjadi lebih aktif di dalam proses pembelajaran, tujuan dari dibuatnya LKS oleh guru dengan multi representasi adalah agar siswa lebih memahami konsep atau materi yang diajarkan dan pembelajaran menjadi lebih bermakna, hal ini sejalan dengan pendapat Aminudin (2015) bahwa keberadaan LKS multi representasi sangat dibutuhkan siswa agar dapat memahami suatu materi. Tahap penerapan, pada tahap ini perwakilan kelompok siswa mengomunikasikan hasil dari diskusi kelompok yang telah dilakukan. Hal ini dilakukan untuk mengetahui 
seberapa jauh pemahaman yang dimiliki siswa pada suatu materi. Pada tahap ini kegiatan presentasi disertai proses tanya jawab kelompok siswa penyaji dan kelompok siswa lainnya, sehingga pembelajaran menjadi lebih interaktif.

Proses pembelajaran dengan model ini dapat membangkitkan kegiatan diskusi siswa di kelas, selain pada tahap penerapan kegiatan diskusi juga dilakukan selama proses pembelajaran berlangsung hal ini dikenal dengan istilah diskursus. Menurut Purwasih (2013) bahwa model pembelajaran Diskursus Multi Representasi merupakan suatu pembelajaran yang berpusat pada siswa dengan membangkitkan diskusi kelompok. Proses pembelajaran diskursus dengan menggunakan berbagai representasi akan mampu meningkatkan konsep matematika karena diskursus dan multi representasi memiliki keterkaitan, hal ini juga sejalan dengan pernyataan Fuad (2016, p.146) bahwa suatu pemahaman objek matematika sangat berkaitan dengan keberadaan representasi internal dalam jaringan representasi dan saling keterkaitannya sehingga dapat mewujudkan suatu representasi eksternal yang bermakna dan dapat di komunikasikan. Tahap Penutup, pada tahap ini siswa merangkum keseluruhan pembelajaran yang telah dilakukan bersama dengan guru dan siswa memperoleh feedback terhadap penguasaan diri terkait materi yang telah diajarkan dengan mengerjakan tes yang diberikan oleh guru.

Berdasarkan uraian tahapan pelaksanaan model Diskursus Multi Representasi yang dilaksanakan pada kelas eksperimen hampir sama dengan tahapan pelaksanaan pembelajaran konvensional yang dilaksanakan di kelas kontrol, yang membedakan adalah LKS yang digunakan pada model Diskursus Multi Representasi dengan LKS yang digunakan pada pembelajaran konvensional. Model Diskursus Multi Representasi menggunakan LKS multi representasi sedangkan LKS pada kelas kontrol yaitu LKS yang di dalamnya hanya memuat soal-soal yang langsung diselesaikan siswa. Penyelesaian LKS yang digunakan dalam model Diskursus Multi Representasi menuntut siswa agar lebih mengonstruksi pengetahuannya untuk menemukan suatu konsep melalui representasi-representasi pada LKS yang dibuat oleh guru. Misalnya pada materi pembelajaran segiempat dan segitiga dengan sub materi luas dan keliling segiempat, yaitu materi luas dan keliling jajargenjang. Luas dan keliling jajargenjang dapat ditentukan dari bangun datar persegi panjang. Di dalam proses mengetahui serta memahami keliling dan luas jajargenjang, pada LKS guru menuntun siswa menggunakan representasi benda konkret yaitu kertas berbentuk jajargenjang yang digunting dan dibentuk menyerupai persegi panjang, sehingga dari kegiatan tersebut siswa juga dituntun guru dalam menggunakan representasi persamaan matematis untuk menentukan rumus dari keliling dan luas jajargenjang, dari kegiatan tersebut siswa mengetahui bahwa rumus keliling dan luas jajargenjang dapat diperoleh dengan pendekatan bangun datar persegi panjang. Salah satu bentuk permasalahan LKS model ini dan telah dikerjakan siswa dapat dilihat Gambar 1.

Berdasarkan lembar jawaban post-test yang dikerjakan siswa kelas eksperimen dan kelas kontrol memiliki perbedaan yang sangat signifikan, hal ini tampak pada analisis persentase jawaban siswa kelas eksperimen dan kelas kontrol seperti pada Tabel 2, terutama pada indikator pertama yaitu menyatakan ulang konsep yang dipelajari dengan kata-kata sendiri yang memiliki rentang persentase antara kelas eksperimen dan kelas kontrol adalah $10,71 \%$. Indikator pertama diukur pada butir soal nomor 2, dimana sebagian besar siswa kelas kontrol hanya menyebutkan jenis segitiga yang dimaksud tanpa menjelaskan pengertian dari segitiga tersebut, sedangkan siswa kelas eksperimen sebagian besar menyebutkan sekaligus menjelaskan pengertian jenis segitiga yang dimaksud soal. Hal ini terjadi pula pada butir soal yang lain salah satunya butir soal nomor 3 yang mengukur indikator mengaplikasikan konsep dalam berbagai situasi, sebagian besar siswa kelas kontrol salah dalam melakukan perhitungan dan salah dalam menuliskan rumus keliling dan luas yang diminta soal, sedangkan siswa kelas eksperimen sebagian besar mengaplikasikan konsep dengan benar dan mampu mengilustrasikan permasalahan yang diberikan sehingga perhitungan yang ditulis dalam lembar jawaban lebih baik dibandingkan dengan siswa kelas kontrol. Hal ini terjadi karena proses penanaman konsep pada kelas ekperimen dan kelas kontrol yaitu terletak pada penyelesaian LKS, dimana pada kelas eksperimen dituntut lebih mengonstruksi pengetahuanya sehingga pembelajaran menjadi bermakna, hal ini sejalan dengan pendapat Niswani (2016) bahwa pembelajaran lebih bermakna karena siswa diberi kesempatan untuk mengonstruksi sendiri pengetahuannya.

Melalui pembelajaran yang bermakna akan berdampak pula pada daya ingat siswa kelas eksperimen lebih baik daripada kelas kontrol seperti mengingat rumus, hal ini ditegaskan 
oleh Gazali (2016) bahwa diperlukan pembelajaran yang bermakna agar pengetahuan yang diperoleh siswa dari proses pembelajaran dapat melekat lebih lama dalam ingatan siswa. Pada proses pembelajaran siswa eksperimen terbiasa menggunakan representasi sesuai dengan konsep yang telah siswa pelajari sehingga dalam penyelesaian suatu masalah seperti butir soal nomor 3, sebagian besar siswa menggambar permasalahan terlebih dahulu dan mengisi unsur-unsur yang diketahui pada gambar serta mengingat pula sifat-sifat dari persegi, sehingga melalui gambar yang dibuat siswa maka siswa tidak akan mengalami kesalahan dalam menafsirkan permasalahan yang diberikan dan benar mensubstitusikan angka pada rumus. Kelompok siswa kontrol sebagian besar masih salah dalam menggunakan rumus pada persoalan, hal ini dikarenakan proses pembelajaran siswa kelompok kontrol lebih cenderung menghafal daripada mengonstruksi pengetahuannya, sehingga pemahaman konsep yang dimiliki masih kurang.

Berdasarkan pembelajaran yang telah dilakukan, penerapan model Diskursus Multi Representasi dapat menyebabkan beberapa hal berikut: (1) pembelajaran akan lebih bermakna bagi siswa sehingga akan berdampak positif pada pemahaman konsep siswa; (2) siswa menjadi lebih aktif di dalam proses pembelajaran; (3) terjalinnya komunikasi yang baik antara siswa dengan siswa dan siswa dengan guru serta siswa dengan lingkungan pembelajaran; dan (4) siswa menumbuhkan rasa percaya diri dan rasa ingin tahu. Manfaat yang sama dari model Diskursus Multi Representasi di atas juga diperoleh Rostika (2017) dalam penelitian yang dilakukannya.

Uraian di atas menunjukkan bahwa kemampuan pemahaman konsep matematika siswa yang dibelajarkan dengan menggunakan model Diskursus Multi Representasi lebih baik dibandingkan dengan menggunakan pembelajaran konvensional. Oleh karena itu, model Diskursus Multi Representai dapat mempengaruhi kemampuan konsep matematika siswa menjadi lebih baik. Model Diskursus Multi Representasi dapat dijadikan sebagai salah satu alternatif pembelajaran yang kreatif dan inovatif dalam upaya peningkatan mutu pendidikan khususnya dalam pelajaran matematika.

\section{SIMPULAN}

Berdasarkan hasil penelitian dan pembahasan, dapat disimpulkan bahwa pemahaman konsep matematika siswa yang dibelajarkan de- ngan model pembelajaran Diskursus Multi Representasi lebih baik dibandingkan dengan pemahaman konsep matematika siswa yang dibelajarkan dengan pembelajaran konvensional. Hal ini menunjukkan bahwa model pembelajaran Diskursus Multi Representasi memberikan pengaruh positif terhadap pemahaman konsep matematika siswa.

Beberapa saran berdasarkan hasil penelitian tersebut, diantaranya: (1) model Diskursus Multi Representasi merupakan model yang inovatif, oleh karena itu disarankan kepada tenaga pendidik untuk menerapkan model ini di dalam proses pembelajaran; (2) peneliti lain yang tertarik disarankan untuk menguji coba pengaruh model ini terhadap aspek pembelajaran yang berbeda, misalnya terhadap kemampuan pemecahan masalah, hasil belajar, prestasi belajar, koneksi matematika maupun aspek pembelajaran yang lainnya; dan (3) peneliti lain dapat melakukan penelitian serupa menggunakan populasi yang lebih besar, sehingga memungkinkan generalisasi yang lebih luas lagi.

\section{DAFTAR PUSTAKA}

Alamsyah, M. (2017). Analisis kesulitan pemahaman konsep matematika dasar pada siswa kelas VIII MTSN Balang-Balang. Skripsi. Jakarta: UIN Syarif Hidayatullah.

Aminudin, M. A. (2015). Pengembangan LKS berbasis multipel representasi pada materi klasifikasi materi. Jurnal Pendidikan dan Pembelajaran Kimia, 4(2), 720-731.

Darmastini, D. P., \& Rosyidi, A. H. (2014). Multi representasi siswa SMP dalam menyelesaikan soal terbuka matematika ditinjau dari perbedaan gender. Jurnal Ilmiah Pendidikan Matematika, 3(1), 5663.

Fuad, M. N. (2016). Representasi matematis siswa SMA dalam memecahkan masalah persamaan kuadrat ditinjau dari perbedaan gender. KREANO: Jurnal Matematika Kreatif-Inovatif, $\quad 7(2), \quad$ 145-152. doi:10.15294/kreano.v7i2.5854

Gazali, R. Y. (2016). Pembelajaran matematika yang bermakna. Math Didactic: Jurnal Pendidikan Matematika, 2(3), 181-190.

Goldin, A. (2002). Representation in mathematical learning and problem solving. In L. D. English (Eds.), Handbook of International Research in Mathematic Education (pp.197-218). New York, NY: Routledge. 
Hendrayana, A. (2017). Pengaruh pembelajaran pendekatan rigorous mathematical thinking (RMT) terhadap pemahaman konseptual matematis siswa SMP. Jurnal Riset Pendidikan Matematika, 4(2), 186199. doi: 10.21831/jrpm.v4i2. 15385

Hudoyo, H. (2007). Mengajar belajar matematika. Jakarta: Depdikbud.

Kartini, K. (2009). Peranan representasi dalam pembelajaran matematika. Prosiding Seminar Nasional Matematika dan Pendidikan Matematika 2009, 361-372.

Kemendikbud. (2014). Permendikbud Nomor 58 Tahun 2014 tentang Kurikulum 2013 Sekolah Menengah Pertama/Madrasah Tsanawiyah.

Mawaddah, S. (2016). Meningkatkan kemampuan pemahaman matematis siswa dengan model pembelajaran quantum teaching di kelas XI SMA. Jurnal Pendidikan Matematika, 4(2), 118-125.

NCTM. (2000). Principles and standards for school mathematics. Reston, VA: Author.

Niswani, N., \& Asdar, A. (2016). The effectivenes of brain based learning model using scientific approacgh in mathematics learning of grade viii students at SMPN 4 Sungguminasa in Gowa District. Jurnal Daya Matematis, 4(3), 349-365.

Nugraheni, E. A., \& Sugiman, S. (2013). Pengaruh pendekatan PMRI terhadap aktivitas dan pemahaman konsep matematika siswa SMP.Pythagoras: Jurnal Pendidikan Matematika, 8(1), 101-108. Retrieved from http://journal.uny. ac.id/index.php/pythagoras/article/view/8 498

Nopitasari, D. (2017). Analisis kemampuan multi representasi matematis berdasarkan kemampuan awal matematis mahasiswa. Jurnal Pedagogy, 2(1), 1-10.

Paul, J. (2003). An introduction to discourse analysis theory and method. London, UK: Routledge.

Purwasih, R. (2013). Pengaruh penggunaan model pembelajaran DMR (Diskursus Multi Representasi) terhadap peningkatan kemampuan komunikasi matematis siswa.
Skripsi. Bandung: Universitas Pendidikan Indonesia.

Purwasih, R., \& Bernad, M. (2018). Pembelajaran diskursus multi representasi terhadap peningkatan kemampuan komunikasi dan disposisi matematis mahasiswa. Jurnal Riset Pendidikan Matematika, 5(1), 43-52. doi: 10.21831/jrpm.v5i1.13589

Renkema, J. (1993). Introduction to discourse studies. Amsterdam, Netherland: John Benjamins Publishing.

Rojak, A. (2017). Analisis pemahaman konsep pada materi perbandingan siswa SMP. Skripsi. Jakarta: UIN Syarif Hidayatullah.

Rostika, D. (2017). Peningkatan kemampuan pemecahan masalah siswa SD dalam pembelajaran matematika dengan model diskursus multy representation (DMR). Jurnal Pendidikan Dasar, 9 (1), 35-46.

Sabirin, M. (2014). Representasi dalam pembelajaran matematika. Jurnal Pendidikan Matematika IAIN Antasari, 1 (2), 33-34.

Sugiyono. (2009). Metode penelitian kuantitatif kualitatif dan $R \& D$. Bandung: Alfabeta.

Suyatno. (2009). Menjelajah pembelajaran inovatif. Sidoarjo: Masmedia Buana Pustaka.

Tianingrum, R., \& Sopiany, H. N. (2017). Analisis kemampuan pemahaman matematis siswa SMP pada materi bangun ruang sisi datar. Prosiding seminar nasional matematika dan pendidikan matematika (SESIOMADIKA), 440-446.

Uno, H. B. (2012). Model pembelajaran. Jakarta: Bumi Aksara.

van Someren, M. W., Reimann, P., Boshuizen, H. P. A., \& De Jong, T. (Eds.). (1997). Learning with multiple representations. Oxford, UK: Elsevier.

Waldrip, B., Prain, V., \& Carolan, J. (2010). Using multi-modal representations to improve learning in junior secondary science. Research in Science Education, 40(1), 65-80. doi: 10.1007/s11165-0099157-6

Yaumi, M. (2012). Pembelajaran berbasis multiple intelligences. Jakarta: Dian Rakyat. 